\title{
Public-Private Partnerships: Determinants of the type of governance structure
}

\section{Jorge Fleta-Asín ${ }^{\mathrm{a}}$, Fernando Muñoz ${ }^{\mathrm{b}}$ and Jorge Rosell-Martínez ${ }^{\mathrm{c}}$}

${ }^{a}$ Economía y Empresa, Centro Universitario de la Defensa, Zaragoza, Spain;

${ }^{b}$ Contabilidad y Finanzas, Universidad de Zaragoza, Zaragoza, Spain; ${ }^{c}$ Economics

Department, University of Southampton, UK.

$a^{a^{*}}$ Área de Economía y Empresa, Centro Universitario de la Defensa. Academia General

Militar. Ctra. De Huesca s/n, 50.090, Zaragoza, Spain. jorge.fleta@unizar.es

${ }^{b}$ Departamento de Contabilidad y Finanzas, Facultad de Economía y Empresa, Gran Vía, 2, 50005, Zaragoza, Spain.fmunoz@unizar.es

${ }^{c}$ Department of Economics, Social Sciences, University of Southampton. SO17 1BJ, Southampton, UK. jrosell@unizar.es

Jorge Fleta-Asín is a PhD Assistant Lecturer at Centro Universitario de la Defensa (CUD), where he teaches courses related to business and management in undergraduate and postgraduate programs. He has published his research in journals such as Journal of International Management and Applied Economic Letters, among others.

Fernando Muñoz is a $\mathrm{PhD}$ Assistant Lecturer at the University of Zaragoza (UZ), where he has taught courses in financial economics and accounting. Previously, he has worked at the Centro Universitario de la Defensa (Zaragoza) where he has taught the subjects of "Business Administration: the Basics" and "Business economics". He has published his research in different academic journals, such as: Business Ethics: A European Review, Journal of Business Ethics, International Review of Economics and Finance, Quantitative Finance, International Review of Financial Analysis or Journal of Empirical Finance, among others.

Jorge Rosell-Martinez is a professor (associate) in the University of Zaragoza. At present, he is visiting scholar at the University of Southampton, UK. His research interests include transaction costs economics, absorptive capacities and competition policy. He has supervised a number of $\mathrm{PhDs}$, research projects, and contracts with firms and institutions.

Acknowledgements: This work was supported by the Centro Universitario de la Defensa under Grant CUD2015-13 and the Government of Aragón (Groups Reference CREVALOR: S42_17R; CIBER Análisis Económico-Financiero de la Empresa y los Mercados and COMPETE: S125) and co-financed with FEDER 2014-2020 "Construyendo Europa desde Aragón”. 


\title{
Public-Private Partnerships: Determinants of the type of governance structure
}

\author{
Despite the spread of Public-Private Partnerships (PPPs) and their interest among \\ academicians and policy-makers, many investigations generally treat them as a \\ homogenous mode of governance neglecting their different forms. The present \\ work investigates the factors that determine the concrete form of PPP finally \\ adopted. We use the Transaction Costs Theory (TCT) to analyse 11,821 PPPs in \\ 110 developing countries from 1997 to 2017. The results show that the greater \\ the amount of specific investment and the more unfavourable the context in \\ which it is implemented, PPP adopts forms where the private party has a greater \\ degree of control.
}

Keywords: public-private partnership; governance structure; transaction costs theory; uncertainty; asset specificity

\section{Introduction}

A public-private partnership (PPP) refers to an agreement between the public and the private sectors, in which some of the services or tasks that are the responsibility of the public sector are provided by the private sector under a clear agreement of shared objectives in order to supply a public service or infrastructure (Carbonara et al., 2014).

This kind of cooperation has particularities that differentiate it from traditional organisational forms, which suppose a challenge for the public management. The most significant are the following: the commonly long duration of PPP, the funding of the project (where the private sector has a relevant role), the participation of a private party in different stages of the project (design, completion, implementation and/or funding) and the distribution of the risk between the public and the private partners ( $\mathrm{Li}$ et al., 2005; Van Ham and Koppenjan, 2010; World Bank, 2016).

This formula is well-received in recent decades because of some advantages. A PPP allows the public management to benefit from the participation of the private sector 
in funding and managing public service expansion by outsourcing risk to private entities (Li et al., 2005; Chou and Pramudawardhani, 2015). This allows for the utilisation of the skills, experience and technology innovation of the private party by the contractor (Li et al., 2005), which could improve the operational efficiency of the public assets (Edkins and Smyth, 2006). Consequently, the government can use its financial capability to undertake other types of activities and concentrate on its core competencies or abilities, by focusing on policymaking, planning and regulation (Felsinger, 2011). However, despite the advantages of PPPs, they can also present some drawbacks. This formula can be used to hide and defer public debt (Buso et al, 2017) and could present extra costs especially in developing countries due to corruption (Hopkin and RodríguezPose, 2007) or their lack of experience in its implementation (Bhattacharya et al, 2014).

Given the importance of PPPs, most studies focus on identifying the risk or critical factors of their implementation for the public and private parties (e.g. Shen et al., 2006; Wang et al, 2018c). However, these studies obtain mixed results due to several reasons (Hodge, 2004; Li et al., 2005; Marques and Berg, 2011). First, studies do not consider the same list of risks, partly because they do not focus on their sources (i.e. the uncertainty) (Wang et al, 2018c). Second, academic papers do not establish differences between types of PPPs, while there are different forms that may shape the criticality of the factors for each party (Cui et al., 2018; Van Den Hurk and Verhoest, 2016). And third, studies do not consider the link between the PPP type adopted and the specific characteristics of the service provided (e.g., its activity or investment amount) (Chang, 2013) and the uncertainty sources where it is located, which some of them can arise from the context in which they operate (Cui et al., 2018). In fact, numerous studies pay attention to the distinctive characteristics of the factors that affect PPPs in developing economies (Pessoa, 2008; Akintoye and Beck, 2009; Osei-Kyei and Chan, 2017). 
Countries transit through different economic development stages (Lucas, 1988;

Schumpeter, 2017). In the first ones, with lowest levels of development, countries are characterized by scarce endowments of productive factors and fragility of their economy (e.g. unstable macroeconomic conditions or underdeveloped legal system) (Porter and Schwab, 2008; Dunning and Lundan, 2008). While in the last stages of development, the most advanced economies already reached higher levels of these factors which may become less critical (e.g. macroeconomic stability or developed legal system) (Dunning and Lundan, 2008; Ramírez and Fleta, 2016; World Economic Forum, 2017). For this reason, developing economies may present different PPP threats related to the greater uncertainty of their contexts (Pessoa, 2008; Liu et al, 2016; OseiKyei and Chan, 2017).

Precisely, the Transaction Costs Theory (TCT) allows us to cover these deficiencies and connect the aforementioned aspects. Thus both, the characteristics of the PPP such as the specificity of the assets (Jin and Doloi, 2008; Musawir et al. 2017), and the uncertainty of the context (Cardenas et al., 2017; Musawir et al., 2017), configure the global level of risk and, in consequence, the governance structure or type of PPP adopted (European Commission, 2004; World Bank, 2016). In this way, the greater the risk that is transferred to the private party, the PPP would adopt a specific form that allows allocating more control to the private party (see Figure 1).

Figure 1. Relationship between types of PPPs, their characteristics and

\section{uncertainty}




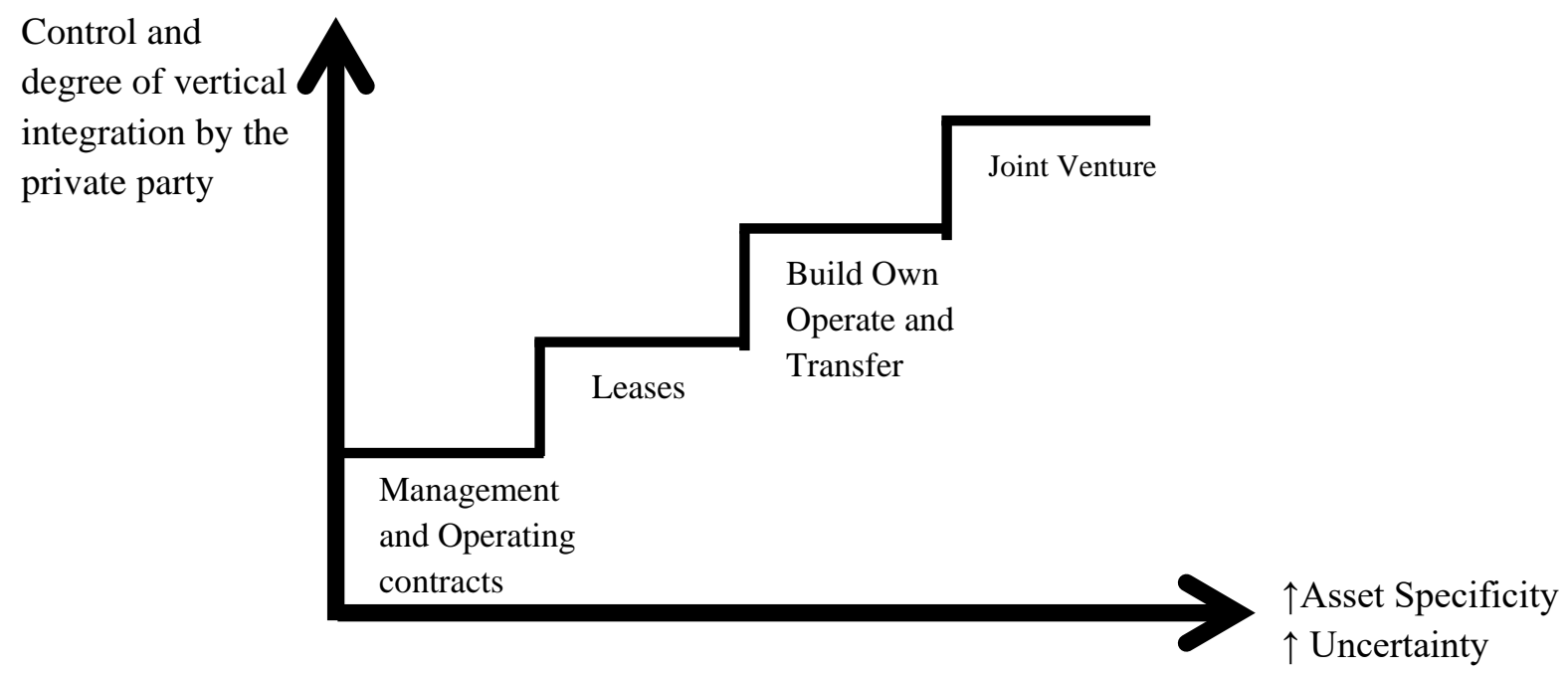

Source: Author elaboration based on European Commission (2004) and World Bank Group (2016).

For these reasons, in the current study, we examine the following research question: How do the sources of uncertainty and characteristics of the transaction influence the type of PPP adopted? We test it on 11,821 infrastructure projects from different sectors in 110 countries, from 1997 to 2017. The data come from countries considered by World Bank as developing economies, that is, excluding the most advanced ones. Some authors (Maurya and Srivastava, 2018) consider that in emerging economies, institutional voids, as unique constraints, limit the deployment of desired governance mechanisms to make PPPs succeed. Our rich dataset contributes to understand how the context along with other project and environment characteristics, affect to the type of PPP finally adopted. .

The structure of the paper is as follows. The second section reviews the academic literature, to analyse how the PPP characteristics and uncertainties influence in the contract types and to formulate the hypotheses. In the third section, we explain the research method, variables, model and data set. In the fourth section, we show the results of testing the hypotheses. The fifth section includes the discussion of the results. Finally, the sixth section shows the main conclusions. 


\section{Theoretical background}

\subsection{External uncertainty}

Uncertainty can arise from the external environment where the transaction takes place. It is associated with the basic conditions necessary for economic activity that cannot be directly controlled by the company (Niknazar and Bourgault, 2017; Zhao et al., 2004). The uncertainty increases with unstable economic, natural and social environments (Slangen and Van Tulder, 2009) that favour the occurrence of events beyond the control of the organisation, hindering productive activities (Abdi and Aulakh, 2012; Zhao et al., 2004). PPPs’ academic literature specially identifies these risks with unstable macroeconomic conditions, such as the volatility of inflation and interest rates (Roumboutsos and Anagnostopoulos, 2008; Mota and Moreira, 2015), few developed financial markets (Xu et al., 2011), expropriation or nationalisation of assets (Marques and Berg, 2011) or social opposition to the project (Chung et al., 2010).

Another source of external uncertainty is the lack of more specific factors in the environment needed for the productive activity. These factors include the level of endowment of basic infrastructures, education and health services, qualified labour or good market efficiency. The scarcity or low quality of them can block or make more expensive economic activities through the markets (Dunning and Lundan, 2008; Ramírez and Fleta, 2016; World Economic Forum, 2017).

In addition, there is another external uncertainty related to instabilities caused by natural events that may affect the success of PPPs. These factors include circumstances, such as force majeure (e.g., floods, storms, etc.) (Li et al., 2005; Marques and Berg, 2011), geotechnical conditions (Li et al., 2005) or other environmental influences (Marques and Berg, 2011; Romboutsos and Anagnostopoulos, 2008). 
The external uncertainties and the capabilities of governments to deal with them are related to the degree of development of the countries. In less-developed countries, the same natural risks have more impact on economic activity than in more-developed ones because of the former's lower capabilities to deal with such risks (Skidmore and Toya, 2002).

Thus, more unstable environments hinder economic activities and increase external risks because the parties cannot rely on the proper functioning of the market (Dunning and Lundan, 2008). In addition, less stable environments have more incidences that may affect the PPPs and, in consequence, are more complex to translate into contracts, making them more difficult to perform, monitor and enforce. For this reason, in less developed countries, vertical integration and hierarchy may be more necessary to take control of some external circumstances (Crocker and Masten, 1988; Luo, 2005).

Economic literature stresses that external uncertainty related to economic instability and deficient productive conditions present more prevalence in developing countries. For this reason, studies consider its impact on PPPs in economies from Latin America, Africa and Asia (Galilea and Medda; 2010; Sharma, 2012); in smaller set of countries such as China, Poland, Russia and Ukraine (Yang et al, 2013); or specific countries such as India (Kurniawan et al, 2013), Sri Lanka (Appuhami et al, 2014), or Nigeria (Babatunde and Perera, 2017). Thus, we propose the following research hypothesis:

Hypothesis 1a (H1a). The higher the external uncertainty where the PPP is carried out, the higher the control by the private party through the type of PPP adopted. 


\subsection{Uncertainty due to contract compliance}

Another source of uncertainty is contract enforcement. To enforce contracts may present difficulties due to incompleteness, which reflects the difficulty of enumerating many contingencies and detailing the PPP specifications ex ante, making it very costly to change the PPP specifications once it is underway (Cruz and Marques, 2012; Iossa and Martimort, 2016).

For instance, there could be a situation where after signing the contract, the contracted organisation neglects those features that were not contained therein, in order to increase its profit (Milgrom and Roberts, 1993). Alternatively, the contracted organisation may require a price increase because of the difficulties of carrying out the service (Crocker and Reynolds, 1993). In these circumstances, difficulty of establishing and enforcing the agreed-upon conditions predisposes the investing organisation to control the activities internally instead of contracting them out in the market (Besanko et al., 2009).

For this reason, the rule of law and degree of development of the legal framework are important (Iossa and Martimort, 2016). The legal ground rules establish the basis for production, exchange and distribution in the market (Oxley, 1999; Williamson, 1985). This approach points out that an adequate legal framework favours economic functioning since investors rely on secure property rights, and it facilitates investment in human and physical capital (Luo, 2005; Oxley, 1999).

An economic system where property rights are fully developed and regulated not only allows for the exchange of goods and services more easily (Dixit, 2009; Mota and Moreira, 2015) but also guarantees compliance and resolution of conflicts or situations not reflected in a contract (Dixit, 2009; Iossa and Martimort, 2016). 
In addition, a developed legal framework means having rules that regulate and allow more complex, novel or unique transactions to take place in a more efficient manner. Conflicts are resolved in an impartial and independent judicial system that does not favour any of the parties in conflict (La Porta et al., 2000). Thus, in the environments where there are developed regulatory frameworks to resolve or lessen the possibility of not fulfilling the contract, the investing party has less necessity of control, because the resolution of the conflicts falls under the legal framework (Oxley, 1999). This connects with the findings by Maurya and Srivastava (2018). These authors point out that in emerging economies, under weak judiciaries and poor law enforcement, governance arrangements are adapted for PPPs to address the institutional voids, taking to suboptimal contracting performance. In fact, from interviews with PPP managers in developing countries such as Nigeria (Babatunde and Perera, 2017), Ghana (Ameyab and Chan, 2013), Indonesia, China or Taiwan (Chou and Pramudawardhani, 2015), the authors highlight the importance of an adequate legal framework that guarantees property rights and regulation of partnerships. Thus, we propose the following hypothesis:

Hypothesis 1b (H1b). The higher the uncertainty, due to contract enforcement where the PPP is carried out, the higher the control of the private party through the type of PPP adopted.

\subsection{Behavioural uncertainty}

Uncertainty can also be caused by the agents' behaviours when one of the parties acts opportunistically by hiding relevant information before signing the contract or by not acting as agreed after signing it (Jin and Doloi, 2008; Milgrom and Roberts, 1993; Williamson, 1979; Williamson, 1985). 
Opportunistic behaviour, or behavioural uncertainty, can arise from both the contracted private company and the public contractor (Fleta-Asín and Muñoz, 2017). Thus, contracts have to contain safeguards that are designed to protect each party from the opportunistic behaviour of the other. Such safeguards are costly and include costs associated with negotiating, drafting and monitoring contracts (Chiles and McMacking, 1996). One approach to controlling the behaviour of agents is to create rules usually in the form of written contracts. However, writing long-term complete contracts in PPPs is very problematic (Parker and Hartley, 2003), and if the contingencies that may occur in the transaction are not reflected in the document, agents can behave opportunistically (Abdi and Aulakh, 2012; Williamson, 1979).

In this situation, trust between the parties may reduce transaction costs because they do not have to plan for all future contingencies, and they can carry out equitable adjustments as market conditions change where the regulatory framework does not apply (Benítez-Ávila et al. 2018; Brogaard, 2017; Dyer and Chu, 2003). Trust decreases drafting costs by allowing contracts to be specified more loosely without ex ante and ex post opportunistic behaviour, and it decreases monitoring costs because of each party's confidence in the other's performance (Adler, 2001; Chiles and McMackin, 1996). When trust is high, each party will assume that the other party is acting in good faith and will interpret behaviours in a more positive way (Abdi and Aulakh, 2012; Warsen et al., 2018), which can serve as a substitute for formal contracts and controls (Dyer and Singh, 1998; Lu et al., 2015).

The specific risks associated with the lack of trust are identified by academics in PPPs, such as the lack of commitment from either partner, third-party tort liability, scarce guarantees provided by the government in the process of collaboration (Li et al., 
2005), a staff crisis or inadequate distribution of responsibilities and risks that are not regulated in the contract (Bing et al., 2005; Li et al., 2005).

The confidence generated by the contracting party, in this case the public sector, is generated by transparent governments where government power is limited and restricted; where corruption is prosecuted; where there are guarantees to carry out the PPP, despite changes in government or laws; and where there is confidence of the society in their politicians and absence of irregular payments or bribes in public procurement (World Economic Forum, 2017). Precisely, circumstances, such as unforeseen legislative changes, changes in the regulation of taxes and in the regulation of the sectors are risk factors for implementing PPPs (Li et al., 2005; Mota and Moreira, 2015; Shen et al., 2006). Casady et al. (2019) refer to this as PPP institutional maturity, which is an important determinant of successful execution and management of PPPs and rests on the public sector's 'legitimacy, trust, and capacity'. Trust is precisely one of the key features in the governance of inter-organizational relationships (Osborne, 2006).

Therefore, the trust between the parties, and especially the contracting government and its integrity, allows the reduction of uncertainty of all those aspects that are not possible to regulate at the time of the formalisation of the contract (Mota and Moreira, 2015; Zheng et al., 2008). Similarly, in the absence of confidence of the private party towards the public one, the private party will prefer to exercise greater control of the organizational form by integrating a larger set of its operations in an organizational form that facilitates it (Chiles and McMackin, 1996). Precisely, previous studies highlight the importance of the credibility and integrity of the public party for PPPs carried out in developing countries such as China (Yang et al, 2013), Sri-Lanka (Appuhami et al, 2011), Sierra Leone ( Harris et al, 2012) or Ghana (Ameyab and Chan, 
2015); as well as in literature reviews focused on other developing economies (Kostyak et al, 2017). Thus, we propose the following hypothesis:

Hypothesis 1c (H1c). The higher the behavioural uncertainty from the public party where the PPP is carried out, the higher the control of the private party through the type of PPP adopted.

\subsection{Asset specificity}

Another relevant characteristic that is related to uncertainty is the degree of specificity acquired by the asset being transacted (Williamson, 1979). In general, when the contracting party goes to the market, the object of exchange would be adapted by the contracted party to meet certain requirements; thus, it acquires a different degree of adaptation to comply with the customer (e.g., specific infrastructures like highways or water supply works) (Besanko et al., 2009). This characteristic is important because once the transaction is agreed upon and a specific degree of specificity is acquired, there may be opportunistic behaviour by the contractor (e.g., the contractor refuses to pay what is agreed upon) or the contracted party (e.g., delivery of low-quality infrastructures), creating an obstruction for the most disadvantaged party (Williamson, 1985).

In general, the greater the specificity of the necessary assets in the productive process, the greater the vulnerability of the contracting party to opportunistic behaviour on the part of the contracted party (De Schepper et al., 2015) since it could increase the prices or decrease the level or quality of services (Ellram et al., 2008). To avoid this risk, the provision of these assets through the market would be the least efficient option for the final economic agent to accept (Grossman and Hart, 1986). Thus, the TCT suggests that activities involving higher uncertainty and specific assets should be internalised (Besanko et al., 2009; Williamson, 1985). 
PPP cases usually present high transaction costs through the market, although the lack of funding and technical skills may pull public managers towards outsourcing them to the private sector (Edkins and Smyth, 2006; Li et al., 2005). According to the TCT, the higher the specificity of the service or product provided by PPPs, the higher the risk associated with the transaction (Jin and Doloi, 2008; Milgrom and Roberts, 1993; Williamson, 1985). As a result, the public party will tend to adopt a specific PPP, in which more risks are transferred to the private party when the presence of specificity of the transaction is greater. In fact, studies performed in developing economies as in China include the asset specificity as an important factor in PPPs (Wang et al, 2018).

Therefore, we propose the following hypothesis:

Hypothesis 2 (H2). The higher the asset specificity of the transaction, the higher the control of the private party through the type of PPP adopted.

Figure 2: Model of the Theoretical Research

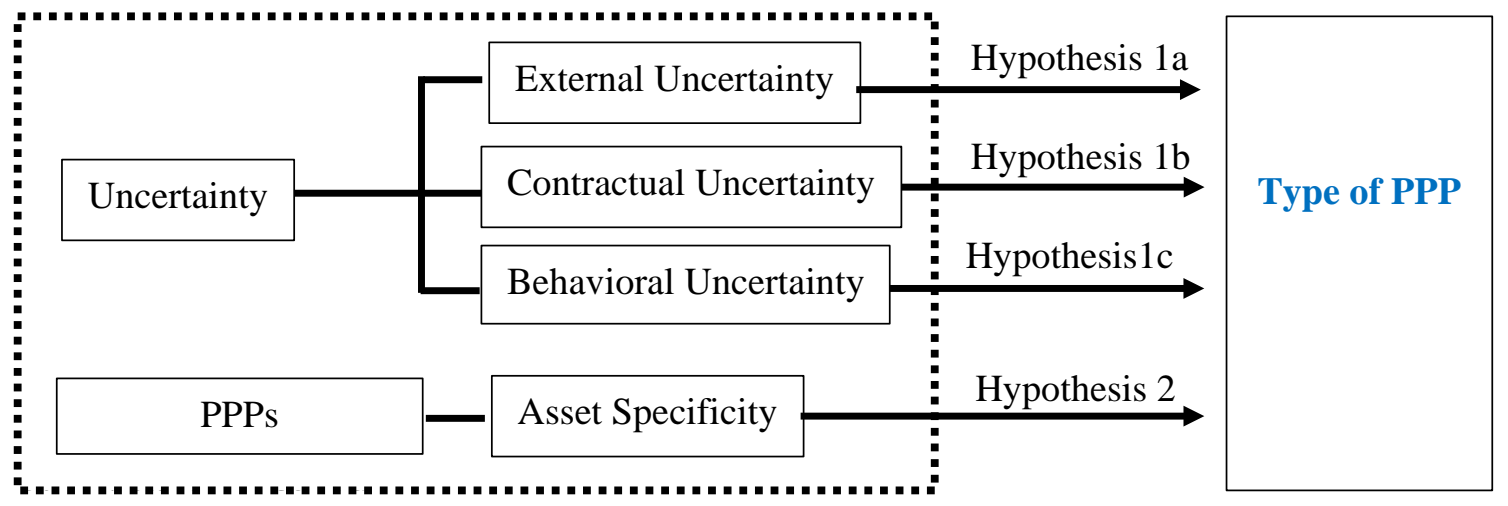

\subsection{Variables}

Following previous studies (Oxley, 1999; Santoro and McGill, 2005), we approach the type of PPP with an ordinal variable from the World Bank PPP Database. We analyse this variable decomposed into two forms in order to check the robustness of the results: one form is aggregated and the other form is disaggregated into more subtypes. Both variables are ordered according to the World Bank, from the lowest control taken by the 
private party up to the highest control (see Appendix). The first proxy, the Governance Structure (GovS), has a range of four values: (1) Management and Lease Contracts, (2) Brownfield, (3) Greenfield Projects and (4) Divestitures. The second proxy, the Governance Structure Subtype (GovSS), ranges from the following: (1) Management contract; (2) Lease contract; (3) Rehabilitate, operate and transfer \& Rehabilitate, lease or rent, and transfer; (4) Build, rehabilitate, operate and transfer; (5) Build, operate and transfer; (6) Build, own and operate; (7) Merchant and Rental; to (8) Partial and (9) full divestiture.

Regarding the external uncertainty (David and Han, 2004), the market or environmental uncertainty within national boundaries is proxied by the degree of development of the countries through gross domestic product (GDP) per capita (Balassa, 1985; Mota and Moreira, 2015; Skidmore and Toya, 2002). Since many variables (e.g., educational and infrastructure level, macroeconomic stability, etc.) are correlated with the degree of development of the country, the use of a proxy for this set of factors avoids severe multicollinearity and facilitates interpretation (Ramírez and Fleta, 2016; Svensson, 1998). Thus, the variable, Development Degree (Dev), is obtained for each country, according to the year before the project started, to represent this development applying logs to the GDP per capita (Ramírez and Fleta, 2016) as previously used to proxy favourable conditions for economic transactions in PPPs (Albalate et al, 2014; Wang et al, 2018b).

The source of uncertainty related to the possibility of an unfulfilled contract is proxied by the International Property Rights Index (PropR) from the Heritage Foundation. It measures the degree to which a country’s laws protect private property rights and the degree to which its government enforces those laws. It contains the level of physical and intellectual property rights, strength of investor protection and quality of 
land administration with values from 0 to 100 . The index is largely used to analyse national contexts (Javorcik, 2004) and other similar indices have been used in PPPs' research (Cardenas et al., 2017; Mota and Moreira, 2015; Panayides et al., 2015).

The source of uncertainty related to the behaviour of the government contractor is proxied by the Government Integrity Index (GovInt), also from the Heritage Foundation. It contains the systemic corruption of government institutions and decision making by such practices as bribery, extortion, nepotism, cronyism, patronage, embezzlement and graft (Jin, 2009). The lack of government integrity caused by such practices reduces economic vitality by increasing costs and shifting resources into unproductive lobbying activities (Nisar, 2013). The index is largely used to analyse national contexts and investment decisions (World Economic Forum, 2017; Carbonara et al., 2014; Cardenas et al., 2017), and its values range from 0 to 100.

Asset Specificity refers to investments in assets that are dedicated to a particular supplier and whose redeployment entails considerable switching costs (Williamson, 1985; Wu et al., 2017). There are several sources of specificity, such as: the location, scale, human resources and the physical assets used for the projected economic activity (Besanko et al., 2009; Milgrom and Roberts, 1993). Given that PPPs are unique projects by nature, where the service is performed and specifically tailored to the government that contracts it, and there is the existence of location specificities per se, the physical assets and the scale used are especially important. In fact, the studies in which Likert scale surveys are used to assess the magnitude ask in particular about the volume of physical assets dedicated (Abdi and Aulak, 2012). Thus, in this PPP study, the asset specificity is proxied by the total physical assets dedicated to the investment (Alvarez, 2010; De Schepper et al., 2015; Lieberman, 1991; Wu et al., 2017). For this purpose, the variable used as a proxy for this characteristic is labelled as Physical Asset 
(PhyInv) investments recorded in millions of US dollars (USD) in either the year of financial closure or year of investment (obtained from the World Bank database). The advantage of this proxy is that it is an objective measure for projects carried out over time in different countries, in contrast to the different perceptions that the people who answer the surveys may have.

Since some PPPs are popularised at different times, and since there are sectors where their maturity and regulation as well as the economic structure of the region affect them (Cui et al., 2018), typical control variables for the investment year, specific economic sectors and continents are included as dummy variables (Oxley, 1999). For the time control variables, four dummy variables are established in symmetric cohorts from the year to be checked that offers enough observations: year 2000 (Y2000), year 2005 (Y2005), year 2010 (Y2010) and year 2015 (Y2015). The variables take the value of one when the project was carried out in that year and zero otherwise. For the sector variables, two variables are included to control the most popular sectors studied, such as the transportation sector (STransp) and the energy sector (SEnergy) (Cui et al., 2018). They reach the values of one when the project was carried out in its sector and zero otherwise. For the continents variables, the projects carried out in Europe (EU), Africa (AFR) and Asia (ASIA) are grouped, taking the value of one if they were located in that continent and zero otherwise.

\subsection{Methods and models}

To test the hypotheses, since the response variable is the governance structure and has different ordered levels, an ordinal logistic regression is used (Oxley, 1999; Santoro and McGill, 2005; Cameron and Trivedi, 2010).

Thus, Models 1 to 4 include the type of PPP in four levels. Model 1 includes only the control variables, Model 2 includes only the variables of the hypotheses, Model 
3 includes the variables of the hypotheses and part of the control variables and, finally, Model 4 includes all the control and hypotheses variables.

To analyse the robustness of the results, Models 5 to 10 are used. Thus, Models 5, 7 and 9 include the hypotheses and control variables of Model 3, considering that PPPs can be nested in countries, regions and continents (Model 5), in countries and regions (Model 7) or only in countries (Model 9). Similarly, Models 6, 8 and 10 check the same nesting levels and variables, decomposing the type of PPP into nine levels. The specification model shown in linear format, including the variables presented, is as follows:

$$
\begin{aligned}
\text { GovS }_{i}=\beta_{0}+ & \beta_{1} \text { PropR }_{i}+\beta_{2} \text { GovInt }_{i}+\beta_{3} \text { Dev }_{i}+\beta_{4} \text { PhyInv }_{\mathbf{i}}+\boldsymbol{\beta}_{\mathbf{5}} \text { Y2000 }_{\mathbf{i}}+\boldsymbol{\beta}_{\mathbf{6}} \text { Y2005 }_{\mathbf{i}} \\
& +\boldsymbol{\beta}_{\mathbf{7}} \text { Y2010 }_{\mathbf{i}}+\boldsymbol{\beta}_{\mathbf{8}} \text { Y2015 }_{\mathbf{i}}+\boldsymbol{\beta}_{\mathbf{9}} \text { SEnergy }_{\mathbf{i}}+\boldsymbol{\beta}_{10} \text { STransp }_{\mathbf{i}}+\boldsymbol{\beta}_{10} \text { EU }_{\mathbf{i}} \\
& +\boldsymbol{\beta}_{\mathbf{1 1}} \text { AFR }_{\mathbf{i}}+\boldsymbol{\beta}_{\mathbf{1 2}} \text { ASIA }_{\mathbf{i}}+u_{\mathrm{i}}
\end{aligned}
$$

where GovS $S_{i}$ is the dependent variable of the governance structure of each PPP for each project, which can reach the value of 1 for the lowest hierarchical form up to 4 , the highest hierarchical form. The subscript $i$ corresponds to each one of the projects carried out in an specific year, $t(\mathrm{i}=1, \ldots, \mathrm{n})$. The variables related to the uncertainty, $\operatorname{PropR}_{\mathrm{i}}(\mathrm{H} 1 \mathrm{a})$, GovInt $_{\mathrm{i}}(\mathrm{H} 1 \mathrm{~b})$ and Devi $(\mathrm{H} 1 \mathrm{c})$ reach the value the previous year of the investment, $t-1$, since the investment is performed considering the previous situation. The variable related to the specificity hypothesis PhyInvi (H2) represents the investment dedicated to the physical assets. After that, the control variables, time (Y2000i, Y2005i, Y2010i, Y2015i), sector (SEnergyi and STranspi) as well as location (EUi, AFRi, ASIA A $_{i}$ are included. Finally, the $\beta$ s are the parameters to be estimated, and $u$ is the random disturbance that is logistically distributed.

In addition, the data could be nested; the projects are carried out in countries with their own contexts, which are related to the country variables used. In multilevel 
models, the random part of the model is more complex to account for the hierarchical structure of the data (Hox, 1998). Consider a single observation, GovS $\mathrm{ijk}_{\mathrm{jk}}$ The observation deviates from its continent mean by an amount that we will denote $e_{i j k}$. The observation's continent mean deviates from the region's mean $\mathrm{u}_{\mathrm{ij}}$, and the observation's regional mean deviates from the fixed part of the model, $\mu$, by an amount that we will denote as $u_{i}$. Thus, the observation's residual is decomposed into three parts or components that describe its magnitude relative to the continent, region and country means. Calculating this set of residuals for each observation, we could estimate the variability of those residuals and make distributional assumptions about them. Thus, the random part of the dependent variable would be as follows: GovS $i_{i j k}=u+u_{i}+u_{i j}+$ $e_{i j k}$

\subsection{Data Set}

To test the hypotheses related to uncertainty (i.e., H1a, H1b and H1c) and asset specificity (H2), we use the public access World Bank Project Database of PPPs (WBPD) as well as indexes from the Heritage Foundation for the country level in the previous investment year. The WBPD collects the information exclusively from publicly available sources, which include commercial news database, specialized and industry publications, government websites and reports or multilateral development agencies, including projects from low and middle-income countries from 1986 until now. For instance, the country with the highest GDP per capita is Russia (16,007 US dollars per capita) and the minimum is the Democratic Republic of Congo (102 US dollars per capita).

The final set without missing data contains 11,821 infrastructure projects from different sectors in 110 countries, collected from 1997 to 2017. The data come from 
countries considered by World Bank as developing economies and their distribution of PPPs by country is shown in Figure 3.

The set includes the type and subtype governance structure of each PPP project, as well as their amount of physical assets. The type of governance structure as the dependent variable, divided into four thresholds, contains the following observations in each category: 232 (Management and Lease contract), 2,342 (Brownfield), 7,567 (Greenfield) and 1,680 (Divestiture) observations, respectively. The subtype of Governance Structure as the dependent variable, divided into nine thresholds, contains the following observations in each category: Management contract (91); Lease contract (141); Rehabilitate, operate and transfer \& Rehabilitate, lease or rent, and transfer (679); Build, rehabilitate, operate and transfer $(1,690)$; Build, operate and transfer $(2,043)$; Build, own and operate (1,937); Merchant and Rental (3,560); Partial $(1,252)$ and full divestitures (428) observations, respectively.

Table 1 summarises the descriptive statistics included in the models, and Table 2 displays the matrix of correlations and individual VIF values that range from 1.02 to 2.18, less than the limit of 10 suggested for multiple regressions models (Kennedy, 1992; Studenmund, 1992) and the stricter limit of 5.3 (Hair et al., 1998). These results show that there is no presence of multicollinearity problems.

Table 1. Descriptive statistics of the data ${ }^{\mathrm{a}}$

\begin{tabular}{|c|c|c|c|c|c|c|c|}
\hline \multicolumn{2}{|l|}{ Variables } & Label & Median & Mean & $\begin{array}{l}\text { Standard } \\
\text { Deviation }\end{array}$ & Min & Max \\
\hline \multicolumn{8}{|c|}{ Dependent Variables } \\
\hline \multicolumn{2}{|c|}{ Governance Structure } & GovS & 3 & 2.904 & 0.640 & 1 & 4 \\
\hline \multicolumn{2}{|c|}{ Governance Struc. Subtype } & GovSS & 6 & 5.904 & 1.639 & 1 & 9 \\
\hline \multicolumn{8}{|c|}{ Independent variables } \\
\hline \multirow{3}{*}{ H1 } & Property Rights & PropR & 50 & 40.356 & 13.368 & 5 & 90 \\
\hline & $\begin{array}{l}\text { Government } \\
\text { Integrity }\end{array}$ & GovInt & 31 & 31.252 & 9.272 & 4 & 70 \\
\hline & $\begin{array}{l}\text { Development } \\
\text { Degree }\end{array}$ & Dev & 7.880 & 7.781 & 1.044 & 4.631 & 9.680 \\
\hline
\end{tabular}




\begin{tabular}{llllllll}
\hline H2 & $\begin{array}{l}\text { Physical } \\
\text { Investments }\end{array}$ & PhyInv & 46.300 & \multirow{2}{*}{166.339} & 401.891 & 0 & \multirow{2}{*}{14800} \\
\hline \multicolumn{2}{c}{ Control variables } & & & & & & \\
\hline \multirow{2}{*}{ Time } & Year 2000 & Y2000 & 0 & 0.044 & 0.207 & 0 & 1 \\
& Year 2005 & Y2005 & 0 & 0.059 & 0.236 & 0 & 1 \\
& Year 2010 & Y2010 & 0 & 0.050 & 0.218 & 0 & 1 \\
& Year 2015 & Y2015 & 0 & 0.027 & 0.164 & 0 & 1 \\
\hline \multirow{2}{*}{ Sector } & Sector Energy & SEnergy & 0 & 0.376 & 0.484 & 0 & 1 \\
& Sector Transport & STransp & 0 & 0.144 & 0.351 & 0 & 1 \\
\hline \multirow{3}{*}{ Continent } & Europe (EU) & EU & 0 & 0.110 & 0.313 & 0 & 1 \\
& Africa (AFR) & AFR & 0 & 0.134 & 0.341 & 0 & 1 \\
& Asia (ASIA) & ASIA & 0 & 0.412 & 0.492 & 0 & 1 \\
\hline
\end{tabular}

a $\mathrm{N}=11821$ observations 
Figure 3. Number of PPPs by location analysed from 1997-2017
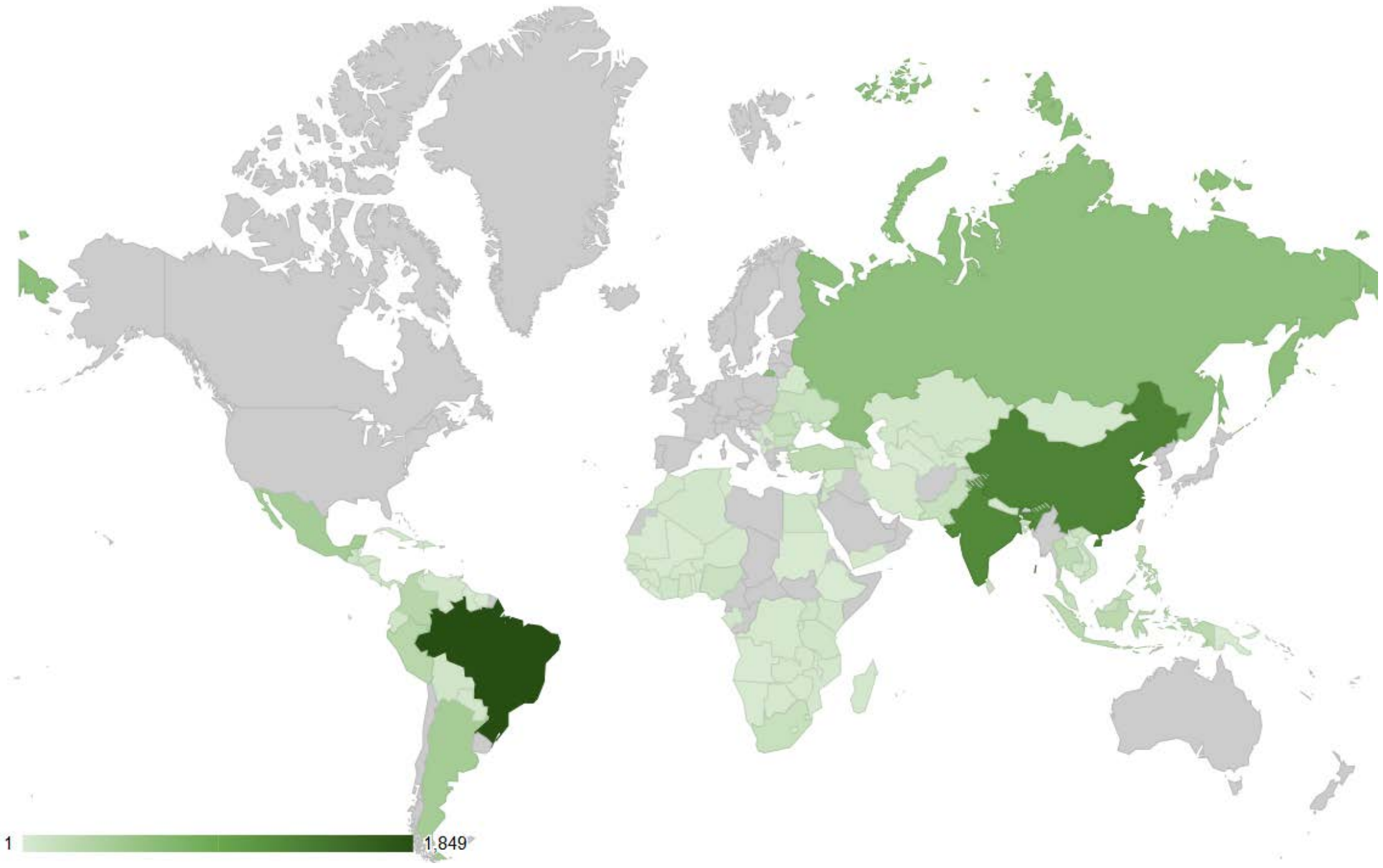
Table 2. Correlation Matrix and individual Variance Inflation Factor (VIF) values ${ }^{\mathrm{a}}$

\begin{tabular}{|c|c|c|c|c|c|c|c|c|c|c|c|c|c|c|c|}
\hline Variable & 1 & 2 & 3 & 4 & 5 & 6 & 7 & 8 & 9 & 10 & 11 & 12 & 13 & 14 & VIF \\
\hline \multicolumn{16}{|l|}{ 1.GovS } \\
\hline 2.GovSS & $0.893 *$ & & & & & & & & & & & & & & \\
\hline 3.PropR & $-0.131^{*}$ & $-0.086 *$ & & & & & & & & & & & & & 1.43 \\
\hline 4.GovInt & $-0.007 *$ & $-0.149 *$ & $0.455^{*}$ & & & & & & & & & & & & 1.67 \\
\hline 5.Dev & $-0.076^{*}$ & $-0.145^{*}$ & $0.150 *$ & $0.424 *$ & & & & & & & & & & & 2.18 \\
\hline 6.PhyInv & $0.046 *$ & $0.032 *$ & $0.070 *$ & $0.057^{*}$ & $0.152 *$ & & & & & & & & & & 1.06 \\
\hline 7.Y2000 & 0.004 & $0.0214 *$ & $0.126 *$ & $-0.046^{*}$ & $-0.086^{*}$ & $-0.032 *$ & & & & & & & & & 1.05 \\
\hline 8.Y2005 & -0.008 & -0.005 & $-0.068 *$ & $-0.044^{*}$ & $-0.097 *$ & $-0.037^{*}$ & $-0.054^{*}$ & & & & & & & & 1.02 \\
\hline 9.Y2010 & 0.000 & 0.011 & $-0.048 *$ & 0.001 & $0.026 *$ & $0.057 *$ & $-0.049 *$ & $-0.057 *$ & & & & & & & 1.02 \\
\hline 10.Y2015 & $-0.036^{*}$ & $-0.074 *$ & -0.007 & $0.051^{*}$ & $0.150 *$ & $0.033^{*}$ & $-0.036^{*}$ & $-0.042^{*}$ & $-0.038 *$ & & & & & & 1.05 \\
\hline 11.SEnergy & $0.042 *$ & $-0.115^{*}$ & $0.036 *$ & $0.166 *$ & $0.224 *$ & 0.002 & $-0.042 *$ & $-0.043 *$ & 0.008 & $0.101^{*}$ & & & & & 1.27 \\
\hline 12.STransp & $-0.370 *$ & $-0.442 *$ & $0.123^{*}$ & $0.056^{*}$ & 0.003 & $0.071^{*}$ & 0.008 & -0.008 & 0.008 & 0.013 & $-0.319 *$ & & & & 1.37 \\
\hline 13.EU & 0.179* & $0.209 *$ & $-0.138 *$ & $-0.117^{*}$ & $0.130 *$ & -0.009 & 0.001 & -0.011 & -0.000 & $-0.051 *$ & $-0.091 *$ & $-0.117^{*}$ & & & 1.33 \\
\hline 14.AFR & $0.052 *$ & $0.135 *$ & $-0.064 *$ & $-0.062 *$ & $-0.336 *$ & $-0.031^{*}$ & -0.004 & $0.043^{*}$ & 0.007 & $-0.020 *$ & $-0.176^{*}$ & $-0.075^{*}$ & $-0.138 *$ & & 1.81 \\
\hline 15.ASIA & -0.010 & $-0.098 *$ & $-0.121 *$ & $-0.038 *$ & $-0.334^{*}$ & 0.004 & $-0.049 *$ & 0.001 & 0.026* & 0.012 & $0.041 *$ & 0.076* & $-0.295 *$ & $-0.330 *$ & 1.95 \\
\hline
\end{tabular}

${ }^{\mathrm{a}} \mathrm{N}=11821$

* $\mathrm{P}<0.05$ 


\section{Results}

Table 3 provides the statistics of four models that include only the control variables (see Model 1), only the hypotheses (see Model 2), as well as the hypotheses with part of the control variables (see Model 3) and with all the control variables (see Model 4).

Results show that, in all models, the likelihood ratio $\chi^{2}$ with a $p$-value less than 0.001 means that the models as a whole are statistically significant, as compared to the null model with no predictors. The intercepts, shown at the bottom of the output, indicate where the latent variable is cut to configure the four groups that we observe in our data. Coefficients of each parameter represent the log odds in order to show the sign of the variables (i.e., instead of showing odds ratios, which coefficients would be positive for all the parameters), with their standard errors in parentheses. For example, in Model 4, for a one-unit increase in property rights (i.e., going from 0 to 1), we expect a -0.01 decrease in the log odds of being in a higher level of the governance structure, given that all of the other variables in the model are held constant.

Thus, according to Model 4, the property rights $\left(\beta_{1}=-0.0119, \mathrm{p}<0.001\right)$ and degree of development $\left(\beta_{3}=-0.1639, p<0.001\right)$ variables are negative and significant. This means that we cannot reject the formulated H1a or H1c hypotheses. Therefore, an increase in the value of these variables (or a reduction in the uncertainty generated by the enforcement of contracts and the development degree) would cause a lesser need to control the activities of the private sector through a governance structure.

Another interesting result is the positive and significant relationship of the physical assets to the governance structure $\left(\beta_{4}=0.0004, p<0.001\right)$. This result shows that the greater the presence of physical assets employed, which approximate the specificity of the transaction, the greater the control that companies try to have over them through greater supervision. Thus, $\mathrm{H} 2$ would not be rejected. 
Finally, Model 4 shows that there is significant and positive relationship between the GovInt $\left(\beta_{2}\right)$ and the GovS variables, opposite as it was expected. In addition, Models 2 and 3, show a positive relationship but not significant. Thus, the H1b proposed would be rejected. Regarding the control variables, specifically for Y2015, sectors and continents are significant in all models; and the Y2005 also excepting in Model 4.

The results together, specifically the rejection of H1b with the fact that the data of the observations may be grouped into hierarchical units (e.g. countries in the first level) and that in the present work the projects are nested in countries with similar characteristics make necessary a more exhaustive examination. 
Table 3. Ordinal Logit Analysis: type governance structure as the dependent variable

\begin{tabular}{|c|c|c|c|c|c|}
\hline Terms & Label & Model 1 & Model 2 & Model 3 & Model 4 \\
\hline \multicolumn{6}{|l|}{ Hypotheses variables } \\
\hline Property Rights & PropR & & $-0.0205(0.00) * * *$ & $-0.0155(0.00) * * *$ & $-0.0119(0.00)^{* * *}$ \\
\hline Government Integrity & GovInt & & $-0.0001(0.00)$ & $0.0040(0.00)$ & $0.0059(0.00) *$ \\
\hline Development Degree & Dev & & $-0.1444(0.01) * * *$ & $-0.1501(0.02) * * *$ & $-0.1639(0.02)^{* * *}$ \\
\hline Physical Investments & PhyInv & & $0.0003(0.00)^{* * *}$ & $0.0005(0.00)^{* * *}$ & $0.0004(0.00)^{* * *}$ \\
\hline \multicolumn{6}{|l|}{ Control variables } \\
\hline Year 2000 & Y2000 & $0.0047(0.09)$ & & $0.0468(0.09)$ & $0.0515(0.09)$ \\
\hline Year 2005 & Y2005 & $-0.1015(0.08)^{*}$ & & $-0.1830(0.08)^{*}$ & $-0.1536(0.08)$ \\
\hline Year 2010 & Y2010 & $-0.0144(0.08)$ & & $-0.0640(0.08)$ & $-0.0701(0.08)$ \\
\hline Year 2015 & Y2015 & $-0.2786(0.11)^{*}$ & & $-0.3101(0.11)^{* *}$ & $-0.2308(0.11)^{*}$ \\
\hline Sector Energy & SEnergy & $-0.3080(0.04)^{* * *}$ & & $-0.3979(0.04) * * *$ & $-0.2738(0.04)^{* * *}$ \\
\hline Sector Transport & STransp & $-2.3914(0.06)^{* * *}$ & & $-2.5247(0.06)^{* * *}$ & $-2.4036(0.06)^{* * *}$ \\
\hline Europe & EU & $1.3639(0.07)^{* * *}$ & & & $1.2542(0.07)^{* * *}$ \\
\hline Africa & AFR & $0.5528(0.06)^{* * *}$ & & & $0.2596(0.07)^{* *}$ \\
\hline Asia & ASIA & $0.4965(0.04)^{* * *}$ & & & $0.2539(0.05)^{* * *}$ \\
\hline Intercept 1 & & $-4.5632(0.08) * * *$ & $-5.8753(0.16)^{* * *}$ & $-6.6224(0.17)^{* * *}$ & $-6.2345(0.23) * * *$ \\
\hline Intercept 2 & & $-1.5430(0.04)^{* * *}$ & $-3.2063(0.14)^{* * *}$ & $-3.5993(0.15)^{* * *}$ & $-3.1877(0.22)^{* * *}$ \\
\hline Intercept 3 & & $2.0288(0.04)^{* * * *}$ & $-0.0512(0.14)^{* * *}$ & $-0.0752(0.15) * * *$ & $0.4242(0.22)^{* * *}$ \\
\hline Likelihood Ratio $\chi^{2}$ & & $2422.61 * * *$ & $336.27 * * *$ & $2275.31 * * *$ & $2585.81 * * *$ \\
\hline Log Likelihood & & -10145.37 & -11188.54 & -10219.02 & -10063.77 \\
\hline Pseudo $\mathrm{R}^{2}$ & & 0.1067 & 0.0148 & 0.1002 & 0.1138 \\
\hline Observations (n) & & 11821 & 11821 & 11821 & 11821 \\
\hline
\end{tabular}

Notes:

${ }^{*} \mathrm{p}<0.05,{ }^{* *} \mathrm{p}<0.01,{ }^{* * *} \mathrm{p}<0.001$. Standard errors are in parentheses.

Type governance structure coded in four levels: Management and lease contract =1, Brownfield=2, Greenfield 3, Divestiture =4 (Appendix Table 5).

Bold format applied in significant results related to the Hypotheses proposed. 


\subsection{Robustness analyses}

To check the robustness of the results, two additional analyses are added to the ordinal logistic regression. On the one hand, a multilevel ordinal regression analysis was applied to elucidate any hierarchical structure in the levels of data collected. Multilevel models enabled us to evaluate how much of the variance in a PPP was attributable to individual circumstances and how much to the conditions of a given level where the projects are nested (i.e., country, region and continent). On the other hand, we conduct the multilevel analysis with the four levels of type of PPP previously analysed, as well as decomposing the GovS into nine levels to check if the grouped results are consistent.

Thus, a model is specified to include cluster-level random effects to account for similarities within clusters, and the observations are assumed to be independently conditional on the random effects (see Table 4). A random intercept captures level differences in the dependent variable across clusters (due to unobserved cluster-level covariates), considering four levels: continents, regions, countries and PPPs (see Models 5 and 6); three levels: regions, countries and PPPs (see Models 7 and 8); and two levels: countries and PPPs (see Models 9 and 10). On the other hand, Models 5, 7 and 9 correspond to the GovS with four ordinal categories, while Models 6, 8 and 10 are the ones with the GovS decomposed into nine ordinal categories. Since the continent level is controlled by the multilevel technique, we exclude continent control variables from the models. The integration model used is the mean-variance adaptive Gauss-Hermite quadrature.

Table 4 results show that, in all models, the Wald chi-square is statistically significant, as compared to the null model with no predictors. Furthermore, the likelihood ratio (LR) test compared with the ordinal logit regression indicates that all the multilevel models are more conveniently considered hierarchically. In addition, we 
perform the LR test to check which of the nested models fits better. Thus, once the nested regressions are performed, the LR test suggests that the best nested model is the two-level model: PPPs nested in countries according to Models 9 and 10 (LR $\chi 2$ Models 10 vs $8=3.61 ; 9$ vs $7=4.16 ; 8$ vs $6=2.27 ; 7$ vs $5=2.00)$. Even though the LR tests indicate that Models 9 and 10 fit better, all Models from 5 to 10 present very similar coefficients estimated and the same sign and significance of the variables related to the hypotheses.

For instance, in Model 9, we find both property rights $\left(\beta_{1}=-0.0101, p<0.001\right)$, physical asset variables $\left(\beta_{4}=0.0005, p<0.001\right)$ and the degree of development $\left(\beta_{3}=-\right.$ 0.1361, $\mathrm{p}<0.01)$ are significant in the same direction as the non-nested ordinal regression model and the hypotheses proposed. Similarly, the governmental integrity variable is not as significant $\left(\beta_{2}=0.0036\right)$ as in the non-nested model. Finally, in Model 9, the 'variance component' or random parameter that estimates the variability accounted for by each level of the hierarchy, reaches the value of 0.7057 .

Additional analyses were performed. For reasons of space, these analyses are not incorporated into the work and can be requested from the authors. We used other proxy for environment uncertainty (log of annual GDP in current dollars), as well as the total assets and the physical ones divided by the total to proxy the asset specificity, finding the same results in terms of sign and significance of the coefficients related to the hypotheses. Models 5 to 10 were performed by introducing the control variables of the continents, as in Models 1 to 4 . In the same way, a multilevel ordinal logistic regression analysis was carried out with different integration methods, such as the mode-curvature adaptive Gauss-Hermite quadrature, non-adaptive Gauss-Hermite quadrature and Laplacian approximation. The same Models were repeated, allowing for the country variables (i.e., property rights, degree of development and integrity of the government) 
with random effects (i.e., a different slope) variable by variable, separately and jointly, as well as models where the variables of the hypotheses that are not significant are excluded. In addition, the models were contrasted, including dichotomous variables for the years 1997 and 2007, to control for global economic cycle. In all cases, the same results were found for the variables of the hypotheses in significance and sign. 
Table 4. Multilevel Ordinal Logistic Regressions: type governance structures as dependent variables ${ }^{\mathrm{a}}$

\begin{tabular}{|c|c|c|c|c|c|c|c|}
\hline \multirow{2}{*}{\multicolumn{2}{|c|}{ Nested Levels }} & \multicolumn{2}{|c|}{ Continent $>$ Region $>$ Country } & \multicolumn{2}{|c|}{ Region $>$ Country } & \multicolumn{2}{|c|}{ Country } \\
\hline & & Model 5 & Model 6 & Model 7 & Model 8 & Model 9 & Model 10 \\
\hline \multicolumn{8}{|c|}{ Hypothesis Variables } \\
\hline \multicolumn{2}{|c|}{ PropR } & $-.0065(0.00)^{* *}$ & $-0.0110(0.00)^{* * *}$ & $-0.0103(0.00)^{* *}$ & $-0.0110(0.00) * * *$ & $-0.0101(0.00) * * *$ & $-0.0108(0.00)^{* * *}$ \\
\hline \multicolumn{2}{|c|}{ GovInt } & $0.0039(0.00)$ & $0.0023(0.00)$ & $0.0034(0.00)$ & $0.0022(0.00)$ & $0.0036(0.00)$ & $0.0022(0.00)$ \\
\hline \multicolumn{2}{|c|}{ Dev } & $-0.1567(0.04) * * *$ & $-0.1794(0.03) * * *$ & $-0.1525(0.04)^{* * *}$ & $-0.1782(0.03) * * *$ & $-0.1361(0.04)^{* *}$ & $-0.1653(0.03)^{* * *}$ \\
\hline \multicolumn{2}{|c|}{ PhyInv } & $0.0005(0.00) * * *$ & $0.0004(0.00)^{* * *}$ & $0.0005(0.00) * * *$ & $0.0004(0.00) * * *$ & $0.0005(0.00) * * *$ & $0.0004(0.00)^{* * *}$ \\
\hline \multicolumn{8}{|c|}{ Control Variables } \\
\hline \multicolumn{2}{|c|}{ Y2000 } & $0.1003(0.10)$ & $0.1189(0.08)$ & $0.1017(0.10)$ & 0.1197 (0.08) & $0.1084(0.10)$ & $0.1249(0.08)$ \\
\hline \multicolumn{2}{|c|}{ Y2005 } & $-0.1351(0.08)$ & $-0.1208(0.07)$ & $-0.1348(0.08)$ & $-0.1210(0.07)$ & $-0.1305(0.08)$ & $-0.1173(0.07)$ \\
\hline \multicolumn{2}{|c|}{ Y2010 } & $-0.0614(0.09)$ & $-0.0398(0.07)$ & $-0.0627(0.09)$ & $-0.0407(0.07)$ & $-0.0674(0.09)$ & $-0.0441(0.07)$ \\
\hline \multicolumn{2}{|c|}{ Y2015 } & $-0.3981(0.11)^{* *}$ & $-0.4295(0.09) * * *$ & $-0.4021(0.11)^{* *}$ & $-0.4311(0.09)^{* * *}$ & $-0.4105(0.11)^{* *}$ & $-0.4369(0.09)^{* * *}$ \\
\hline \multicolumn{2}{|c|}{ SEnergy } & $-0.0088(0.05)$ & $-1.1012(0.04)^{* * *}$ & $-0.0083(0.05)$ & $-1.0999(0.04)^{* * *}$ & $-0.0093(0.05)$ & $-1.1018(0.04)^{* * *}$ \\
\hline \multicolumn{2}{|c|}{ STransp } & $-2.3593(0.06)^{* * *}$ & $-3.4950(0.06)^{* * *}$ & $-2.3582(0.06)^{* * *}$ & $-3.4938(0.06) * * *$ & $-2.3583(0.06)^{* * *}$ & $-3.4949(0.06)^{* * *}$ \\
\hline \multicolumn{2}{|c|}{ Intercept 1} & $-7.0197(0.38) * * *$ & $-9.3889(0.34)^{* * *}$ & $-6.9594(0.36)^{* * *}$ & $-9.3402(0.29) * * *$ & $-6.8044(0.34)^{* * *}$ & $-9.2277(0.30)^{* * *}$ \\
\hline \multicolumn{2}{|c|}{ Intercept 2} & $-3.7959(0.38)^{* * *}$ & $-8.4352(0.33)^{* * *}$ & $-3.7352(0.35) * * *$ & $-8.3865(0.28)^{* * *}$ & $-3.5796(0.33)^{* * *}$ & $-8.2739(0.29)^{* * *}$ \\
\hline \multicolumn{2}{|c|}{ Intercept 3} & $0.1488(0.37)^{*}$ & $-6.8230(0.32) * * *$ & $0.2093(0.34)^{*}$ & $-6.7742(0.30) * * *$ & $0.3644(0.32)^{*}$ & $-6.6611(0.28)^{* * *}$ \\
\hline \multicolumn{2}{|c|}{ Intercept 4} & & $-5.1775(0.32)^{* * *}$ & & $-5.1286(0.30) * * *$ & & $-5.0149(0.28)^{* * *}$ \\
\hline \multicolumn{2}{|c|}{ Intercept 5} & & $-3.8028(0.32) * * *$ & & $-3.7537(0.29) * * *$ & & $-3.6397(0.28)^{* * *}$ \\
\hline \multicolumn{2}{|c|}{ Intercept 6} & & $-2.6047(0.32)^{* * *}$ & & $-2.5554(0.29)^{* * *}$ & & $-2.4416(0.28)^{* * *}$ \\
\hline \multicolumn{2}{|c|}{ Intercept 7} & & $-0.4769(0.32)^{*}$ & & $-0.4277(0.29)^{*}$ & & $-0.3143(0.27) *$ \\
\hline \multicolumn{2}{|c|}{ Intercept 8} & & $1.0776(0.32)^{* *}$ & & $1.1266(0.29)^{* * *}$ & & $1.2398(0.28)^{* * * *}$ \\
\hline \multirow{3}{*}{$\begin{array}{c}\text { Random } \\
\text { parameters }\end{array}$} & Continent & $0.1167(0.12)$ & $0.0756(0.07)$ & & & & \\
\hline & Region & $0.0243(0.06)$ & $0.0202(0.04)$ & $0.1170(0.08)$ & $0.0832(0.06)$ & & \\
\hline & Country & $0.6029(0.11)$ & $0.4757(0.08)$ & $0.6031(0.11)$ & $0.4779(0.08)$ & $0.7057(0.12)$ & $0.5511(.09)$ \\
\hline \multicolumn{2}{|c|}{ Wald $\chi^{2}$} & $1553.41 * * *$ & $3038.15^{* * *}$ & $1552.35 * * *$ & $3035.81 * * *$ & $1549.73 * * *$ & $3033.71 * * *$ \\
\hline \multicolumn{2}{|c|}{ LR test vs. Ologit } & $1288.03 * * *$ & $1840.38 * * *$ & $1286.03 * * *$ & $1838.11^{* * *}$ & $1281.87 * * *$ & $1834.50 * * *$ \\
\hline \multicolumn{2}{|c|}{ Observations } & 11821 & 11821 & 11821 & 11821 & 11821 & 11821 \\
\hline \multicolumn{2}{|c|}{ Pseudo R ${ }^{2}$} & 0.12 & 0.25 & 0.10 & 0.25 & 0.12 & 0.26 \\
\hline
\end{tabular}

a Notes:

${ }^{*} \mathrm{p}<0.05,{ }^{* *} \mathrm{p}<0.01, * * * \mathrm{p}<0.001$. Standard errors are in parentheses.

Governance structure with 4 or 9 levels. See Appendix.

The number of groups in each level analysis include 5 continents, 17 regions and 110 countries, hierarchically nested in each other from the latter to the first one.

Bold format applied in significant results related to the Hypotheses proposed. 


\section{Discussion}

Regarding the characteristics of the transaction, both the theoretical approaches and the empirical studies support the notion that asset specificity affects the way in which the transaction is managed (De Schepper et al., 2015; Wu et al 2017). Thus, PPPs that present greater specificities tend to adopt contractual forms in which the party (the

private one) that carries out the investment has a greater control (Benítez-Ávila, 2018; Wu et al., 2017). When the private party faces a PPP, the bigger the investment, the higher the part of the property of the assets involved in the transaction that the private party should retain. This way, the private party reduces the potential losses caused by opportunism of the public party.

About the uncertainties in which the investment is carried out, the TCT exposes their importance in the management of the PPP (De Schepper et al., 2015; Wang et al., 2018, 2018b). Among them, the relevance of the external uncertainties (mainly arising from market environments) stands out (Albalate et al, 2014; Mota and Moreira, 2015). In fact, in our study, we find that the uncertainty of the environment, proxy trough the level of development of the economies, influence the type of PPP adopted. These results are in the same line of those found by Wang et al (2018). These authors study a sample of 705 projects in China and observe that higher transactions costs can increase the control of the private partnerships.

Another source of uncertainty may arise from the enforcement of the contracts. This uncertainty is related with the legal framework (Panayides et al., 2015) since it depends on the location in which the PPP tries to govern the transaction (Lu et al., 2015). Thus, the relationship between legal environments and increased investment in port PPPs has been studied for large groups of developing countries (Panayides et al., 2015), as well as various projects in the EU (Mota and Moreira, 2015), finding positive 
and significant relationships. In the present work, in line with other findings in previous literature (Cardenas et al., 2017), the importance of the institutional environment in the way of managing PPPs is pointed out. In particular, property rights are shown as a variable that influences the type of PPP adopted, so that the more protection is granted by the regulatory framework where the transaction takes place, the more the private party delegates to the market aspects that are controlled by this institutional framework.

Thus, according to the TCT and the present empirical study, the specificity of the assets and uncertainty related to markets and legal frameworks, not only imply a greater degree of control from the private party, but also imply that this control can be established in a staggered way through different types of PPPs.

However, regarding the GovInt variable, our results indicate that this source of uncertainty related to trust does not affect the final configuration of the PPP governance. Studies such as Benítez-Ávila et al. (2018) did not find a positive relationship between the government positive orientation towards PPPs and higher private participation in them. Other studies on PPPs relate the trust between the parties with the best climate of cooperation and performance (Warsen et al., 2018). Lu et al. (2015) prove that contractual governance is more effective than relational governance through trust to improve project performance. However, our focus is different from previous studies since we implement the analyses from the contracted perspective party.

Our findings show that behavioural uncertainty on the public party may be irrelevant if the legal context for contracting guarantees an adequate enforcement and fulfilment of contracts. This empirical evidence could be due to the principle of pacta sunt servanda (Von Glahn and Taulbee, 2017), for which a developed and reliable legal framework is enough for the fulfilment of the agreement. Under a deficient rule of law, 
a significant behavioural uncertainty on the public party may cause difficulties for PPPs development.

Thus, not all kinds of uncertainties would affect in the same way the governance structure of a PPP. Sources should be decomposed in order to not to have spurious relationships. Our results seem to indicate that the ease of enforcing the contract because of the property rights level and the degree of development of the country, other forms of uncertainty are less relevant.

\section{Conclusions}

The analyses carried out in this paper recommend addressing the peculiarities of each transaction according to the uncertainty related to the market conditions (i.e. external uncertainty) and legal framework (i.e. contractual uncertainty), as well as the investment specificity, in order to analyse the PPP type convenience. Our results show that the greater the specificity and uncertainty in the project, the greater the control of the project in hands of the private party of the PPP. Whether this choice is made by the public sector or induced by the private party, the election eases the viability of the PPP, avoiding that contracting procedures result unsuccessful due to implicit costs of the transaction.

Thus, in general, there is an alignment between transaction characteristics, context where it is located and governance structure adopted by a manager. These findings are complementary and compatible with international papers and guidelines on PPPs, shedding light on the importance of different aspects of the context where transaction takes place. Furthermore, trust and reliability to the public party does not seem to affect the type of PPP adopted. This may be because an adequate legal framework reduces uncertainty independently of the behavioural uncertainty from the public side. Analogously, the weaker the legal framework, the bigger the influence that 
this uncertainty would have in the governance choice for the PPP. These results are robust to individual location of the contract (continent, region, country) and also when decomposing the type of PPP into more cases.

However, this study has several limitations that should be taken into account for future research. The first one is about the data used. Although the database is broad for many countries and from an international organisation, PPPs from countries with the highest degree of development are not included. Thus, we should be cautious with the generalisations of some of the results obtained in this paper. This means that the economic literature that suggests that there are factors at the country level, whose importance for economic activities depends on their level of economic development, must be taken into account in the argumentation of the hypotheses when dealing with these types of economies (Ramírez and Fleta, 2016).

The second limitation or caution is related to the variables used to prove some of the hypotheses. For instance, the results should be contrasted with other proxies (e.g. from International Transparency or Governance Indicators databases) instead the property rights and government integrity from Heritage Foundation. In the same way, it would be convenient to replicate the study with other variables used in the study related to the uncertainty of the environments.

Third, although it is novel to analyse the private party’s trust in the public party, because the investigation is located in the private decision maker, the variable could be further refined if there are project-specific data that assesses the confidence of both parties (Benítez-Ávila et al., 2018; Warsen et al., 2018).

These limitations, derived of the available information, show that further research would provide additional results by combining factors that affect different levels, such as those of the company that manages the project, as for example, the 
trustworthiness towards the private party (Kostyak et al, 2017), its technical expertise (Ameyab and Chan, 2015) or previous experience (Galilea and Medda, 2010); or additional characteristics of the specific project and other proxies to assess the specificity assumed by the private party.

Besides, since our findings indicate nested behaviours, regional idiosyncrasies of PPP forms between geographical areas need more exploration in order to detect other types of regional effects (e.g., economic areas, geophysical similarities, etc.).

This wide-scope research could may well lead to research at a local level of institutional facilities and how these affect the type of PPP adopted. As noted by Torres and Pina (2001) or Kivilä et al. (2017), among others, there may be local government regulations that affect how projects are organised. 


\section{Appendix}

Table 5. Type of governance structure of Public-Private Partnerships

\begin{tabular}{|l|l|}
\hline \multicolumn{1}{|c|}{ Aggregated structure } & \multicolumn{1}{|c|}{ Disaggregated structure } \\
\hline \multirow{5}{*}{ 1. Management and Lease contracts } & $\begin{array}{l}\text { 1. Management contract: Management contracts transfer } \\
\text { responsibility for managing a utility to a private operator, } \\
\text { often for three to five years. The ones considered PPPs are the } \\
\text { ones that aim for efficiency by defining performance targets } \\
\text { and basing the fee in part on their fulfilment. }\end{array}$ \\
\hline & $\begin{array}{l}\text { 2. Lease contract. The term "lease" is used here for a class of } \\
\text { arrangements under which an operator is responsible for } \\
\text { operating and maintaining the business, but not for financing } \\
\text { and investment }\end{array}$ \\
\hline \multirow{5}{*}{ 2. Brownfield projects } & $\begin{array}{l}\text { 3. Rehabilitate, operate, and transfer. A private sponsor } \\
\text { rehabilitates an existing facility, then operates and maintains } \\
\text { the facility at its own risk for the contract period. }\end{array}$ \\
\hline & $\begin{array}{l}\text { 4. Build, rehabilitate, operate and transfer. A private developer } \\
\text { builds an add-on to an existing facility or completes a partially } \\
\text { built facility and rehabilitates existing assets, then operates and } \\
\text { maintains the facility at its own risk for the contract period. }\end{array}$ \\
\hline \multirow{5}{*}{ 3. Greenfield projects } & $\begin{array}{l}\text { 5. Build, operate and transfer. A private sponsor builds a new } \\
\text { facility at its own risk, owns and operates the facility at its own } \\
\text { risk, then transfers the facility to the government at the end of } \\
\text { the contract period. }\end{array}$ \\
\hline $\begin{array}{l}\text { 6. Build, own, and operate. A private sponsor builds a new } \\
\text { facility at its own risk, then owns and operates the facility at its } \\
\text { own risk. }\end{array}$ & $\begin{array}{l}\text { 7. Merchant. A private sponsor builds a new facility in a } \\
\text { liberalized market in which the government provides no } \\
\text { revenue or payment guarantees. The private developer assumes } \\
\text { construction, operating, and market risk for the project. Rental } \\
\text { private sponsor places a new facility at its own risk, owns and } \\
\text { operates the facility at its own risk. }\end{array}$ \\
\hline $\begin{array}{l}\text { 8. Partial divestiture: The government transfers part of the } \\
\text { equity in the state-owned company to private entities. The } \\
\text { private stake may or may not imply private management of the } \\
\text { facility. }\end{array}$ \\
\hline $\begin{array}{l}\text { 9. Full divestiture: The government transfers 100 percent of the } \\
\text { equity in the state owned company to private entities. }\end{array}$ \\
\hline
\end{tabular}

Source: World Bank ppi.worldbank.org 


\section{REFERENCES}

Abdi, M., \& Aulakh, P.S. (2012). Do country-level institutional frameworks and interfirm governance arrangements substitute or complement in international business relationships?. Journal of International Business Studies, 43(5), 477-497.

Adler, P.S. (2001). Market, hierarchy, and trust: The knowledge economy and the future of capitalism. Organization Science, 12(2), 215-234.

Akintoye, A. \& Beck, M. (2009). Policy, finance \& management for public-private partnerships. West Sussex, UK: Wiley-Blackwell.

Albalate, D., Bel, G., \& Geddes, R. R. (2015). The determinants of contractual choice for private involvement in infrastructure projects. Public Money \& Management, 35(1), 87-94.

Alvarez-Suescun, E. (2010). Combining transaction cost and resource-based insights to explain IT implementation outsourcing. Information Systems Frontiers, 12(5), 631-645.

Ameyaw, E.E., \& Chan, A.P. (2015). Evaluation and ranking of risk factors in public-private partnership water supply projects in developing countries using fuzzy synthetic evaluation approach. Expert Systems with Applications, 42(12), 5102-5116.

Appuhami, R., Perera, S., \& Perera, H. (2011). Coercive policy diffusion in a developing country: The case of Public-Private Partnerships in Sri Lanka. Journal of Contemporary Asia, 41(3), 431451.

Babatunde, S.O., \& Perera, S. (2017). Barriers to bond financing for public-private partnership infrastructure projects in emerging markets: A case of Nigeria. Journal of Financial Management of Property and Construction, 22(1), 2-19.

Balassa, B. (1985). Exports, policy choices, and economic growth in developing countries after the 1973 oil shock. Journal of Development Economics, 18(1), 23-35.

Benítez-Ávila, C., Hartmann, A., Dewulf, G., \& Henseler, J. (2018). Interplay of relational and contractual governance in public-private partnerships: The mediating role of relational norms, trust and partners' contribution. International Journal of Project Management, 36(3), 429-443.

Besanko, D., Dranove, D., Shanley, M., \& Schaefer, S. (2009). Economics of strategy. John Wiley \& Sons, New Jersey.

Bhattacharya, A, Romani, M., \& Stern, N. (2012). Infrastructure for Development: Meeting the Challenge. Policy paper sponsored by The Centre for Climate Change Economics and Policy, the Grantham Research Institute on Climate Change and the Environment, in collaboration with the Intergovernmental Group of Twenty-Four on International Monetary Affairs and Development (G-24) (June).

Bing, L., Akintoye, A., Edwards, P.J., \& Hardcastle, C. (2005). The allocation of risk in PPP/PFI construction projects in the UK. International Journal of Project Management, 23(1), 25-35.

Brogaard, L. (2017). The impact of innovation training on successful outcomes in public-private partnerships. Public Management Review, 19(8), 1184-1205.

Buso, M., Marty, F., \& Tran, P.T. (2017). Public-private partnerships from budget constraints: Looking for debt hiding?. International journal of industrial organization, 51, 56-84.

Cameron, A.C., \& Trivedi, P.K. (2010). Microeconometrics using stata (Vol. 2). College Station, TX: Stata press. 
Carbonara, N., Costantino, N., \& Pellegrino, R. (2014). Concession period for PPPs: A win-win model for a fair risk sharing. International Journal of Project Management, 32(7), 1223-1232.

Cardenas, I.C., Voordijk, H., \& Dewulf, G. (2017). Beyond theory: Towards a probabilistic causation model to support project governance in infrastructure projects. International Journal of Project Management, 35(3), 432-450.

Casady, C.B., Eriksson, K., Levitt, R.E. \& Scott, W.R. (2019): (Re)defining public-private partnerships (PPPs) in the new public governance (NPG) paradigm: an institutional maturity perspective, Public Management Review, DOI:10.1080/14719037.2019.1577909

Chang, C.Y. (2013). A critical review of the application of TCE in the interpretation of risk allocation in PPP contracts. Construction Management and Economics, 31(2), 99-103.

Chiles, T.H., \& McMackin, J.F. (1996). Integrating variable risk preferences, trust, and transaction cost economics. Academy of Management Review, 21(1), 73-99.

Chou, J.S., \& Pramudawardhani, D. (2015). Cross-country comparisons of key drivers, critical success factors and risk allocation for public-private partnership projects. International Journal of Project Management, 33(5), 1136-1150.

Chung, D., Hensher, D.A., \& Rose, J.M. (2010). Toward the betterment of risk allocation: Investigating risk perceptions of Australian stakeholder groups to public-private-partnership tollroad projects. Research in Transportation Economics, 30(1), 43-58.

Crocker, K.J., \& Masten, S.E. (1988). Mitigating contractual hazards: Unilateral options and contract length. The RAND Journal of Economics, 327-343.

Crocker, K.J., \& Reynolds, K.J. (1993). The efficiency of incomplete contracts: an empirical analysis of air force engine procurement. The RAND Journal of Economics, 126-146.

Cruz, C.O., \& Marques, R.C. (2012). Using the economic and financial reequilibrium model to decrease infrastructure contract incompleteness. Journal of Infrastructure Systems, 19(1), 58-66.

Cui, C., Liu, Y., Hope, A., \& Wang, J. (2018). Review of studies on the public-private partnerships (PPP) for infrastructure projects. International Journal of Project Management, 36(5), 773-794.

David, R.J., \& Han, S.K. (2004). A systematic assessment of the empirical support for transaction cost economics. Strategic Management Journal, 25(1), 39-58.

De Schepper, S., Haezendonck, E., \& Dooms, M. (2015). Understanding pre-contractual transaction costs for Public-Private Partnership infrastructure projects. International Journal of Project Management, 33(4), 932-946.

Dixit, A. (2009). Governance institutions and economic activity. American Economic Review, 99(1), 5-24.

Dunning, J., Lundan, S.M., (2008). Multinational enterprises and the global economy. UK, Edward Elgar Publishing.

Dyer, J.H., \& Chu, W. (2003). The role of trustworthiness in reducing transaction costs and improving performance: Empirical evidence from the United States, Japan, and Korea. Organization Science, 14(1), 57-68.

Dyer, J.H., \& Singh, H. (1998). The relational view: Cooperative strategy and sources of interorganizational competitive advantage. Academy of Management Review, 23(4), 660-679. 
Edkins, A.J., Smyth, H.J. (2006). Contractual management in PPP projects: evaluation of legal versus relational contracting for service delivery. Journal of Professional Issues in Engineering Education and Practice, 132 (1), 82-93.

Ellram, L.M., Tate, W.L. \& Billington, C. (2008). Offshore outsourcing of professional services: A transaction cost economics perspective. Journal of Operations Management, 26(2), 148-163.

European Commission (2004). Green Paper on Public Private Partnerships and Community Law on Public Contracts and Concessions, COM (2004) 327, Brussels.

Felsinger, K. (2011). Access 01/07/2017. Public-Private Partnership handbook. Washington, DC: World Bank: Available at: http://documents.worldbank.org/curated/en/490511468331774007/Public-Private-Partnershiphandbook

Fleta-Asín, J., \& Muñoz, F. (2017). Determinants of contract duration in outsourced services in the defense sector. Applied Economics Letters, 24(19), 1408-1411.

Galilea, P., \& Medda, F. (2010). Does the political and economic context influence the success of a transport project? An analysis of transport public-private partnerships. Research in Transportation Economics, 30(1), 102-109.

Grossman, S.J. \& Hart, O.D. (1986). The costs and benefits of ownership: A theory of vertical and lateral integration. The Journal of Political Economy, 94(4), 691-719.

Hair J.F., Tatham RL, Anderson RE. Multivariate Data Analysis. 5. Prentice Hall; 1998.

Harris, D., Kooy, M., \& Jalloh, G. (2012). The political economy of the urban water-pricing regime in Freetown, Sierra Leone. London: ODI.

Hodge, G. A. (2004). The risky business of public-private partnerships. Australian Journal of Public Administration, 63(4), 37-49.

Hopkin, J., \& Rodríguez-Pose, A. (2007). “Grabbing Hand” or “Helping Hand”?: corruption and the economic role of the state. Governance, 20(2), 187-208.

Hox, J. (1998). Multilevel modeling: When and why. In Classification, data analysis, and data highways. Springer, Berlin, Heidelberg.

Iossa, E., \& Martimort, D. (2016). Corruption in PPPs, incentives and contract incompleteness. International Journal of Industrial Organization, 44, 85-100.

Javorcik, B. S. (2004). The composition of foreign direct investment and protection of intellectual property rights: Evidence from transition economies. European Economic Review, 48(1), 39-62.

Jin, X.H. (2009). Determinants of efficient risk allocation in privately financed public infrastructure projects in Australia. Journal of Construction Engineering and Management, 136(2), 138-150.

Jin, X.H., \& Doloi, H. (2008). Interpreting risk allocation mechanism in public-private partnership projects: an empirical study in a transaction cost economics perspective. Construction Management and Economics, 26(7), 707-721.

Kennedy, P.A. (1992). Violating Assumption Five: Multicollinearity. Guide to Econometrics. Oxford, United Kingdom: Blackwell, 192-202.

Kivilä, J., Martinsuo, M., \& Vuorinen, L. (2017). Sustainable project management through project control in infrastructure projects. International Journal of Project Management, 35(6), 1167-1183. 
Kostyak, L., Shaw, D. M., Elger, B., \& Annaheim, B. (2017). A means of improving public health in low-and middle-income countries? Benefits and challenges of international public-private partnerships. Public health, 149, 120-129.

Kurniawan, F., Ogunlana, S., Motawa, I., \& Dada, M. (2013). Public-private partnership projects implementation: three case studies of seaport projects in India. University of Central Lancashire (UCLAN) Preston, UK 18-20 March 2013, 65.

La Porta, R., Lopez-de-Silanes, F., Shleifer, A., \& Vishny, R. (2000). Investor protection and corporate governance. Journal of Financial Economics, 58(1), 3-27.

Li, B., Akintoye, A., Edwards, P.J., \& Hardcastle, C. (2005). Critical success factors for PPP/PFI projects in the UK construction industry. Construction Management and Economics, 23(5), 459471.

Lieberman, M.B. (1991). Determinants of vertical integration: An empirical test. Academy of Management Proceedings, Academy of Management. 1991(1), 31-35.

Liu, T., Wang, Y., \& Wilkinson, S. (2016). Identifying critical factors affecting the effectiveness and efficiency of tendering processes in Public-Private Partnerships (PPPs): A comparative analysis of Australia and China. International Journal of Project Management, 34(4), 701-716.

Lu, P., Guo, S., Qian, L., He, P., \& Xu, X. (2015). The effectiveness of contractual and relational governances in construction projects in China. International Journal of Project Management, 33(1), 212-222.

Lucas Jr, R. E. (1988). On the mechanics of economic development. Journal of monetary economics, 22(1), 3-42.

Luo, Y. (2005). Transactional characteristics, institutional environment and joint venture contracts. Journal of International Business Studies, 36(2), 209-230.

Marques, R.C., \& Berg, S. (2011). Risks, contracts, and private-sector participation in infrastructure. Journal of Construction Engineering and Management, 137(11), 925-932.

Maurya, D. \& Srivastava, A.K. (2018): Managing partner opportunism in public-private partnerships: the dynamics of governance adaptation, Public Management Review, DOI: 10.1080/14719037.2018.1559341.

Milgrom, P., \& Roberts, J. (1993). Economics, Organization and Management. Prentice-Hall, New Jersey.

Mota, J.A., \& Moreira, A.C. (2015). The importance of non-financial determinants on publicprivate partnerships in Europe. International Journal of Project Management, 33(7), 1563-1575.

Musawir, A., Serra, C.E.M., Zwikael, O., \& Ali, I. (2017). Project governance, benefit management, and project success: Towards a framework for supporting organizational strategy implementation. International Journal of Project Management, 35(8), 1658-1672.

Niknazar, P., \& Bourgault, M. (2017). Theories for classification vs. classification as theory: Implications of classification and typology for the development of project management theories. International Journal of Project Management, 35(2), 191-203.

Nisar, T. M. (2013). Implementation constraints in social enterprise and community public private partnerships. International Journal of Project Management, 31(4), 638-651.

Osborne, S.P. (2006). The New Public Governance?. Public Management Review, 8(3), 377-387. 
Osei-Kyei, R., Chan, A.P., Javed, A.A., \& Ameyaw, E.E. (2017). Critical success criteria for public-private partnership projects: international experts' opinion. International Journal of Strategic Property Management, 21(1), 87-100.

Oxley, J.E. (1999). Institutional environment and the mechanisms of governance: the impact of intellectual property protection on the structure of inter-firm alliances. Journal of Economic Behavior \& Organization, 38(3), 283-309.

Panayides, P.M., Parola, F., \& Lam, J.S.L. (2015). The effect of institutional factors on publicprivate partnership success in ports. Transportation Research Part A: Policy and Practice, 71, 110127.

Parker, D., \& Hartley, K. (2003). Transaction costs, relational contracting and public private partnerships: a case study of UK defence. Journal of Purchasing and Supply Management, 9(3), 97-108.

Pessoa, A. (2008). Public-private partnerships in developing countries: are infrastructures responding to the new ODA strategy?. Journal of International Development: The Journal of the Development Studies Association, 20(3), 311-325.

Porter, M.E., \& Schwab, K. (2008). The global competitiveness report 2008-2009. In World Economic Forum.

Ramírez-Alesón, M., \& Fleta-Asín, J. (2016). Is the importance of location factors different depending on the degree of development of the country?. Journal of International Management, 22(1), 29-43.

Roumboutsos, A., \& Anagnostopoulos, K. P. (2008). Public-private partnership projects in Greece: Risk ranking and preferred risk allocation. Construction Management and Economics, 26(7), 751-763.

Santoro, M.D., \& McGill, J. P. (2005). The effect of uncertainty and asset co-specialization on governance in biotechnology alliances. Strategic Management Journal, 26(13), 1261-1269.

Schumpeter, J.A. (2017). Theory of economic development. Routledge.

Sharma, C. (2012). Determinants of PPP in infrastructure in developing economies. Transforming government: people, process and policy, 6(2), 149-166.

Shen, L.Y., Platten, A., \& Deng, X.P. (2006). Role of public private partnerships to manage risks in public sector projects in Hong Kong. International Journal of Project Management, 24(7), 587594.

Skidmore, M., \& Toya, H. (2002). Do natural disasters promote long-run growth?. Economic inquiry, 40(4), 664-687.

Slangen, A.H., \& Van Tulder, R.J. (2009). Cultural distance, political risk, or governance quality? Towards a more accurate conceptualization and measurement of external uncertainty in foreign entry mode research. International Business Review, 18(3), 276-291.

Studenmund, A.H., \& Cassidy, H.J. (1992). Using econometrics: A practical guide. AddisonWesley Educational Publishers.

Svensson, J. (1998). Investment, property rights and political instability: Theory and evidence. European Economic Review, 42(7), 1317-1341.

Torres, L., \& Pina, V. (2001). Public-private partnership and private finance initiatives in the EU and Spanish local governments. European Accounting Review, 10(3), 601-619. 
Van Den Hurk, M., \& Verhoest, K. (2016). The challenge of using standard contracts in publicprivate partnerships. Public Management Review, 18(2), 278-299.

Van Ham, H., \& Koppenjan, J. (2010). Building public-private partnerships: Assessing and managing risks in port development. Public Management Review, 3(4), 593-616.

Von Glahn, G., \& Taulbee, J. L. (2017). Law among nations: an introduction to public international law. Routledge.

Wang, H., Chen, B., Xiong, W., \& Wu, G. (2018). Commercial investment in public-private partnerships: the impact of contract characteristics. Policy \& Politics, 46(4), 589-606.

Wang, H., Liu, Y., Xiong, W., \& Zhu, D. (2018b). Government Support Programs and Private Investments in PPP Markets. International Public Management Journal, 1-25.

Wang, H., Xiong, W., Wu, G., \& Zhu, D. (2018c). Public-private partnership in Public Administration discipline: a literature review. Public Management Review, 20(2), 293-316.

Warsen, R., Nederhand, J., Klijn, E.H., Grotenbreg, S., \& Koppenjan, J. (2018). What makes public-private partnerships work? Survey research into the outcomes and the quality of cooperation in PPPs. Public Management Review, 20(8), 1165-11851-21.

World Economic Forum (2017). Schwab, K. (Ed.). The Global Competitiveness Report 20172018. Geneva.

Williamson, O.E. (1979). Transaction-cost economics: the governance of contractual relations. The Journal of Law and Economics, 22(2), 233-261.

Williamson, O.E. (1985). The economic institutions of capitalism. Macmillan Publishers: London, UK.

World Bank Group (2016). Access 01/02/2018. Available from: http://ppp.worldbank.org/publicprivate-partnership/

Wu, A., Wang, Z., \& Chen, S. (2017). Impact of specific investments, governance mechanisms and behaviors on the performance of cooperative innovation projects. International Journal of Project Management, 35(3), 504-515.

Xu, Y., Yang, Y., Chan, A.P., Yeung, J.F., \& Cheng, H. (2011). Identification and allocation of risks associated with PPP water projects in China. International Journal of Strategic Property Management, 15(3), 275-294.

Yang, Y., Hou, Y., \& Wang, Y. (2013). On the development of public-private partnerships in transitional economies: An explanatory framework. Public Administration Review, 73(2), 301310.

Zhao, H., Luo, Y., \& Suh, T. (2004). Transaction cost determinants and ownership-based entry mode choice: A meta-analytical review. Journal of International Business Studies, 35(6), 524-544.

Zheng, J., Roehrich, J.K., \& Lewis, M.A. (2008). The dynamics of contractual and relational governance: evidence from long-term public-private procurement arrangements. Journal of Purchasing and Supply Management, 14(1), 43-54. 